\title{
The b'x Region of Yeast Protein Disulfide Isomerase is Not Essential for Saccharomyces cerevisiae Viability at $30^{\circ} \mathrm{C}$
}

\author{
PURKAN $^{1,2}$, LALU RUDYAT TELLY SAVALAS $^{1,3}$, MULIAWATI SINDUMARTA $^{1}$, AND DESSY NATALIA ${ }^{1 *}$ \\ ${ }^{1}$ Biochemistry Research Division, Faculty of Mathematics and Natural Sciences, Institut Teknologi Bandung, \\ Jalan Ganesha 10, Bandung 40132, Indonesia, ${ }^{2}$ Chemistry Department, Faculty of Sciences and Technology, \\ Universitas Airlangga, Jalan Mulyorejo, Surabaya 60115, Indonesia, ${ }^{3}$ Chemistry Department, Faculty of Science Education, \\ Universitas Mataram, Jalan Majapahit 62, Mataram 85125, Indonesia
}

Protein disulfide isomerase (PDI) catalyzes thiol oxidation, reduction and isomerization of disulphide bond of cell surface and secreted proteins. Yeast PDI1 consists of two catalytic domains (a and a') which are separated by two non-catalytic domains (b and $\mathrm{b}^{\prime}$ ), and a $\mathrm{x}$ region linked the $\mathrm{b}^{\prime}$ and a domains. The b' domain is important for the non-covalent binding of partially folded protein. To understand the contribution of $b^{\prime}$ domain and $\mathrm{x}$-linker of yeast PDI1 we have deleted the b' $\mathrm{x}$ and investigated its functional role in vitro and in vivo. Yeast PDI1 without b'x region retained only 50\% activity and became more sensitive toward Proteinase K. Interestingly, yeasts containing full length $P D I 1$ and $p d i 1 \Delta b^{\prime} x$ showed approximately the same growth rate. However, the yeast pdil $\Delta b^{\prime} x$ mutant growth impaired severely at $37^{\circ} \mathrm{C}$ compared to that of the full length PDII. Our results suggested that the a-b-a'-c domains of PDI seems to be sufficient to support the growth of yeast cells in normal condition, but the b'x region might be essential in assisting refolding of highly accumulated unfolded protein at high temperature $\left(37^{\circ} \mathrm{C}\right)$.

Key words: b'domain, protein disulfide isomerase, Saccharomyces cerevisiae, $\mathrm{x}$-linker

Formation of correct disulfide bonds is essential for proper folding of the majority of cell surface and secreted proteins in eukaryotic cells. Protein disulfide isomerase (PDI), which is a resident of the endoplasmic reticulum (ER), catalyzes the formation, reduction and isomerization of disulfide bonds. It has also a chaperone role which mediates the folding and assembly of nascent peptides into mature proteins in the cells (Wang and Tsou 2003). The chaperone activity is independent of its catalytic activity as it has been demonstrated that PDI improves secretion of redox-inactive $\beta$-glucosidase (Powers and Robinson 2007). In addition, PDI is found to form a complex with other protein molecules, namely prolyl-4 hydroxylase and microsomal triglyceride transfer protein (Pihlajaniemi et al. 1987; Wetterau et al. 1991).

Protein disulfide isomerase is composed of four thioredoxin-like domains, a,b, b' and a', folowed by an acidic C-terminal extension (named as c) harboring ER retention signal (Freedman et al. 1994). The a and a' domains each contain active site sequence CXXC which is required for disulphide bond formation. The b' domain of human PDI contributes significantly to protein substrate interactions (Klappa et al. 2000; Denisov et al. 2009).

In Saccharomyces cerevisiae PDI is encoded by an essential gene PDII (Farquhar et al. 1991). The three dimensional structure of yeast PDI1 has a twisted U-shape in which the $a$ and a' domain facing each other on the end of $U$ while the $b$ and b' domain forming the base (Tian et al. 2006). The b' and a' domains is connected by 17 residues which is referred as $x$-linker. The crystal structure shows that the $b$ and b' domains have hydrophobic patch which together with hydrophobic areas surrounding the active sites, form a continuous hydrophobic surfaces across the a, b' and a' domain (Tian et al. 2006). These hydrophobic residues are involved in the interaction of PDI with its substrates.

"Corresponding author, Phone: +62-22-2502103, Fax: +62-22-2504154, E-mail: dessy@chem.itb.ac.id
In this paper we described that yeast pdi1 without b'x region still maintains half of its insulin reductase activity, although it becomes more sensitive toward Proteinase K compared to that of full length PDI1. Furthermore, we demonstrated that pdi $1 \Delta b^{\prime} x$ can support yeast viability.

\section{MATERIALS AND METHODS}

Materials. Plasmid pRS314-PDII (a generous gift from Prof. W. J. Lennarz, Department of Biochemistry and Cell Biology, State University of New York at Stony Brook, USA) containing $P D I 1$ was used as a template for amplification of a DNA fragment encoding for pdi1 without b'x. Escherichia coli DH5 $\alpha$ was used for plasmid propagation and BL21 (DE3) (ara, leu7967, lacX74, phoA, PvuII, phoR, malF3, F' [lac, lac $\left.\left.\left.I^{q}\right), \operatorname{pro}\right], \operatorname{trx} B:: k a n(D E 3)\right)$ was used for expression host of PDI proteins. Yeast S. cerevisiae strain 2736 (MATa ade2-1 can1-100 ura3-1 leu2-3,112 trp1-1 his3-11,15 pdi1::HIS3) containing pCT37-PDII [URA3] (obtained from Prof. T. H. Steven, Institute of Molecular Biology, University of Oregon, USA) and pUKC639 (kindly provided by Prof. M. F. Tuite, School of Biosciences, University of Kent, United Kingdom) were used for plasmid shuffling in yeast cell. Plasmid pT7.7 (Novagen, Madison, WI) was used for expression of a pdi$\Delta b^{\prime} x$ mutant in E. coli. Plasmid pGEM ${ }^{\circledR}-\mathrm{T}$, Vent and Taq DNA polymerases were obtained from Promega. Restriction enzymes and T4 DNA ligase were obtained from New England Biolabs, Inc. All synthetic DNA oligomers were synthesized by Pro-Oligo Singapore. Yeast cells were grown in minimal medium $[0.7 \%(\mathrm{w} / \mathrm{v})$ yeast nitrogen base (YNB) without amino acid, $2 \%(\mathrm{w} / \mathrm{v})$ glucose or $2 \%(\mathrm{w} / \mathrm{v})$ galactose] supplemented with approriate amino acids and bases, and YEPD/Gal yeast extract $[(1 \%(\mathrm{w} / \mathrm{v}),(\mathrm{w} / \mathrm{v})$ bacto peptone $1 \%,(\mathrm{w} / \mathrm{v})$ glucose $2 \%$, (w/v) galactose $2 \%)]$ media. Escherichia coli was grown in Luria-Bertani (LB) (Sambrook et al. 1989).

Construction of $p d i 1 \Delta b$ ' $x$ Mutant. A yeast PDI lacking b' $x$ region coded by nucleotides at position 739-1149 in PDII gene was constructed through 3 steps of PCR (Fig 1) using 


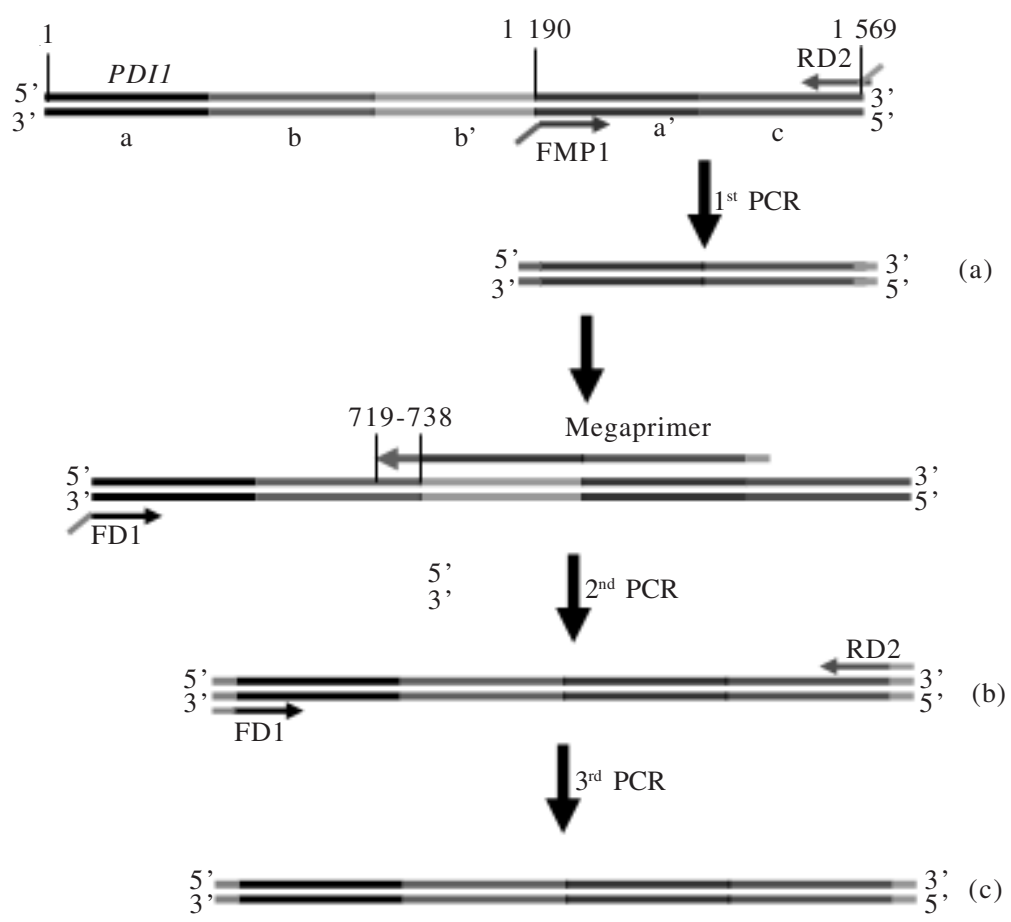

Fig 1 Strategy of deletion of DNA fragment encoding b'x region of yeast PDII using three steps PCR. The first PCR was performed to produce a 447 bp DNA fragment encoding a'c domain (a). The resulted fragment was used as a mega primer together with FD1 primer in the second PCR to produce a pdilÄb'x mutant. A low concentration of pdiläb'x mutant (b) was obtained at this step. The third PCR was conducted to increase the concentration of pdilÄb'x mutant using FD1 and RD1 primers. This step gave a high concentration of pdilÄb'x mutant (c).

pRS314-PDI1 as a template. Oligonucleotide primers for PCR were designed based on published sequences of PDIl gene (Accession number 850314). Primers FMP1(5'-ACT TTGGTGAAATCGACGGTAAGAACCATGACGAA-3') and RD2 (5'-GAGGAGGATCCTTACAATTCATCGTGAATGG3') were used to amplify a DNA fragment corresponding to coding region 1150-1569 of PDI1. The FMP1 contained 20 nucleotides corresponding to the coding region 719-738 of PDI1, while RD2 primer had a Bam $\mathrm{H} 1$ restriction site.

The resulted DNA fragment from the first round PCR as a reverse mega primer together with primer FD1 (5'-GAG GAC ATA TGA AGT TTT CTG CTG GTG-3') and a template of pRS314-PDII were used in the second PCR. The third PCR was carried out using primers forward FD1 and reverse RD2 (5'-GAGGAGGATCCTTACAATTCATCGTGAATGG-3'), and the second PCR results as a template. All PCR products were analyzed by agarose gel electrophoresis and purified by GFX purification kit.

The resulted $p d i 1 \Delta b^{\prime} x$ DNA fragment was ligated with $\mathrm{pGem}^{\circledR}$-T vector and the the ligation product was transformed into E. coli $\mathrm{DH} 5 \alpha$ using $\mathrm{CaCl}_{2}$ method (Sambrook et al. 1989). The pGem ${ }^{\circledR}$-T-pdil $\Delta b^{\prime} x$ was digested with NdeI and BamHI restriction enzymes and the resulted 1400 bp pdil $\Delta b$ ' $x$ fragment was isolated and then ligated with an expression vector previously digested with $\mathrm{NdeI}$ and BamHI. The resulted pT7-7-pdil $\Delta b^{\prime} x$ was confirmed by restriction analysis. The pT7-7-pdil $\Delta b^{\prime} x$ was subjected to DNA sequence analysis.

Construction of pdi1 $\Delta \boldsymbol{b}$ ' $x$ in Yeast Expression Plasmid. Plasmid pT7.7-pdil $\Delta b^{\prime} x$ as a template, and primers PDIF1 (GCTAGCATGAAGTTTTCTGCTGGTGC) and PDIR1 (GCTAGCTTACAATTCATCGTGAATGGC) were used to amplify pdil $\Delta b$ ' $x$. The PCR program was $94^{\circ} \mathrm{C}$ for $4 \mathrm{~min}$,
25 cycles of $1 \mathrm{~min}$ at $94^{\circ} \mathrm{C}, 1 \mathrm{~min}$ at $55^{\circ} \mathrm{C}, 2 \mathrm{~min}$ at $72{ }^{\circ} \mathrm{C}$ and $5 \mathrm{~min}$ at $72^{\circ} \mathrm{C}$. NheI sites were included in both forward and reverse primers. The PCR products were gel purified, subcloned into $\mathrm{pGem}{ }^{\circledR}$-T vector. A NheI fragment of pdil $\Delta b$ ' $x$ taken out from $\mathrm{pGem}^{\circledR}$-T-pdil $\Delta b^{\prime} x /$ NheI was then inserted into pUKC639 previously digested with similar restriction enzyme. The resulted pUKC639-pdil $\Delta b$ ' $x$ was sequenced to confirm the presence of the deletion.

Transformation of Yeast. The resulted pUKC639pdil $\Delta b$ ' $x$ was used to transform $S$. cerevisiae 2736 using a modified lithium acetate method (Ito et al. 1983). The transformed cells were plated onto minimal medium supplemented with $0.001 \%(\mathrm{w} / \mathrm{v})$ adenine and $0.002 \%(\mathrm{w} / \mathrm{v})$ tryptophan and grown at $30{ }^{\circ} \mathrm{C}$ for $4-7 \mathrm{~d}$.

Plasmid-Shuffling. The yeast transformants carrying pUKC639-pdi1 $\Delta b ' x$ were grown in solid minimal medium containing $2 \%(\mathrm{w} / \mathrm{v})$ galactose, $1 \mathrm{mg} \mathrm{mL}^{-1} 5$ 'fluoroorotic acid (5'FOA), $0.002 \%(\mathrm{w} / \mathrm{v})$ tryptophan, $0.001 \%(\mathrm{w} / \mathrm{v})$ adenine and $0.001 \%(\mathrm{w} / \mathrm{v})$ uracil at $30{ }^{\circ} \mathrm{C}$ for $4-7 \mathrm{~d}$. The yeast cells designated as $2736 \mathrm{D}$ were then transferred into a minimal medium supplemented with similar amino acid and bases.

Protein Expressions. Escherichia coli strain BL21 (DE3) carrying PDII or pdil $\Delta b^{\prime} x$ genes on plasmid pT7-7 were grown in $10 \mathrm{~mL} \mathrm{LB}$ media containing $100 \mathrm{~g} \mathrm{~mL}^{-1}$ ampicillin at $37^{\circ} \mathrm{C}$ for $16 \mathrm{~h}$. One $\mathrm{mL}$ of overnight culture was transferred into a fresh $50 \mathrm{~mL} \mathrm{LB} /$ ampicillin media and grown until the culture $\mathrm{OD}_{600}$ reached 0.5 . Isopropyl- $\alpha$-thiogalactopyranoside (IPTG) was added to the culture to a final concentration of $0.5 \mathrm{mM}$ and the culture was grown for further $2.5 \mathrm{~h}$. Cell cultures were precipitated by centrifugation at $2100 \mathrm{x} g$ for 30 min at $4{ }^{\circ} \mathrm{C}$. The pellet cells were resuspended in lysis buffer (50 mM Tris- $\mathrm{HCl} \mathrm{pH} 7.5,0.2 \mathrm{mM} \mathrm{NaCl}$ dan $10 \%$ glycerol) containing $1 \mathrm{mg} \mathrm{mL}^{-1}$ lysozyme. Cells were lysed using 
sonication with 10x 1 min burst at maximum frequency and cooled on ice for $1 \mathrm{~min}$ after each $1 \mathrm{~min}$ burst. The lysed cells was then centrifuged at $9500 \mathrm{x}$ g for $30 \mathrm{~min}$ at $4{ }^{\circ} \mathrm{C}$.

Assay of PDI Protein Activities. The ability of PDI1 to reduce disulphide bond was determined as described by Sutter et al. (1994). The assay mixture contained $1.67 \mathrm{mM}$ insulin in $100 \mathrm{mM}$ potassium phosphate buffer, $\mathrm{pH}$ 7.0, $20 \mathrm{mM}$ ethylene diamine tetraacetic acid, crude bacterial cell extract PDI, $10 \mathrm{mM}$ dithiothreitol. The increase of OD at $650 \mathrm{~nm}$ from precipitation of insulin $\mathrm{B}$ chain was measured. One unit activity was defined as an amount of PDI to reduce disulfide bonds of insulin in order to produce $\Delta \mathrm{A} 650$ of 0.001 per min at experimental condition.

Stability Test of Mutant pdi1 $\Delta \mathbf{b} \mathbf{b} \mathbf{x}$. Stability of mutant PDI toward proteinase $\mathrm{K}$ was conducted based on method described by Klappa et al. (2000). PDI was mixed with various concentration of Proteinase $\mathrm{K}\left(1 ; 3 ; 10 \mathrm{mg} \mathrm{mL}^{-1}\right)$ in PBS buffer ( $\mathrm{NaCl} 140 \mathrm{mM}, \mathrm{KCl} 2.7 \mathrm{mM}, \mathrm{Na}_{2} \mathrm{HPO}_{4} 10 \mathrm{mM}, \mathrm{KH}_{2} \mathrm{PO}_{4} 1.8$ $\mathrm{mM}, \mathrm{pH} 8$ ) for $30 \mathrm{~min}$ at $4{ }^{\circ} \mathrm{C}$. The reaction was stopped with $5 \mathrm{mM}$ phenyl methyl sulphonyl fluride (PMSF) for $5 \mathrm{~min}$.

SDS-Polyacrylamide Gel Electrophoresis and Westernblotting. Protein electrophoresis was performed as described by Laemmli (1970). Protein blotting was done by using semi-dry blotter (BioRad). Protein in the gel was transferred onto nitrocellulose membrane (Hybond ECL). The membrane was incubated with an antibody anti PDI and subsequently with the peroxidase-conjugated anti rabbit Ig antibody. The signal was developed using ECL detection reagent (Amersham).

\section{RESULTS}

Yeast pdi1 $\Delta b$ ' $x$ has been Generated by Three Steps PCR. Yeast $p d i 1 \Delta b^{\prime} x$ mutant was constructed by deletion of a 7391146 DNA region of PDI1 corresponding to Ser247-Gly383 using three steps of PCR (Fig 2B). The first PCR was performed to amplify the DNA fragment at nucleotide position of 1150 to 1569 corresponding to the a'c domains. The resulted DNA fragment with the size of $447 \mathrm{bp}$ also contained 20 oligonucleotides of $b$ domain (Fig 3, lane 3). The oligonucleotide of a'c domain was used as a reverse mega primer in combination with FD1 primer to generate a low yield of $1190 \mathrm{bp}$ DNA fragment corresponding to aba'c domain in the second PCR (Fig 3, lane 4). To increase the amount of the 1190 bp pdil $\Delta b$ ' $x$ DNA fragment, a third PCR using FD1 primer and RD2 primer was performed. The resulted DNA fragment (Fig 3, lane 5) was first ligated with $\mathrm{pGem}^{\circledR}{ }^{\circledR}$-T plasmid and then subcloned into pT7.7 expression vector. The sequence of the $1190 \mathrm{bp}$ was confirmed by dideoxynucleotide sequence analysis and found to be free of mutation. A full length PDII generated by PCR was also subcloned into pT7-7 plasmid.

Mutant pdi1 $\Delta b^{\prime} \times x$ Produced as a Soluble Protein in $E$. coli. The full length $P D I 1 / p d i 1 \Delta b^{\prime} x$ gene is placed under the control of $\phi 10$ promoter which requires T7 RNA polymerase to activate the promoter. The host E. coli strain used had already been transfected with phage DE3 containing the T7 RNA polymerase gene. The T7 RNA polymerase was under the control of of inducible lacUV5 promoter and thus addition

a

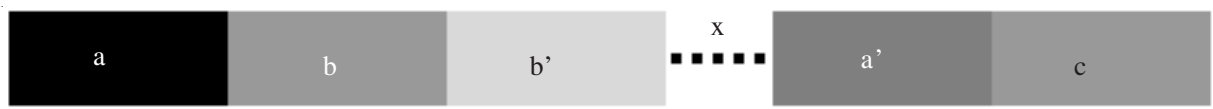

$\mathrm{b}$

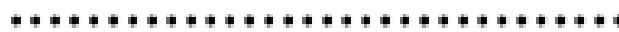

yeast PDIl Sc.PRO nXIIA

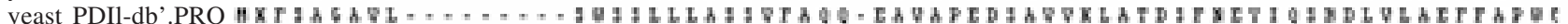

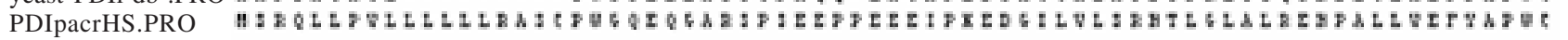
61

yeast PDIl Sc.PRO G t T

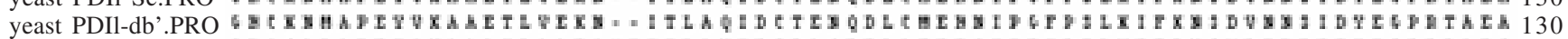

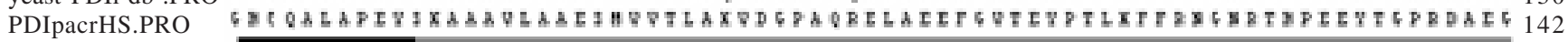

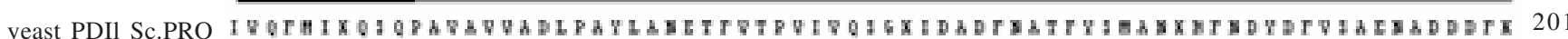

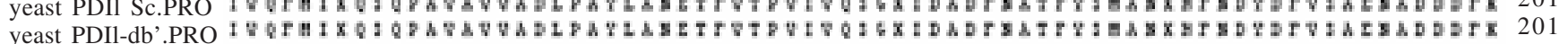

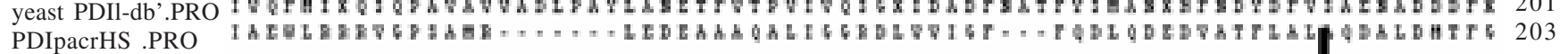

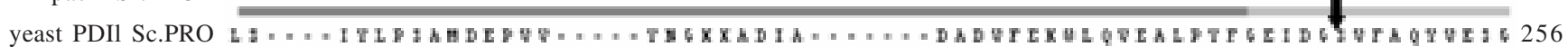

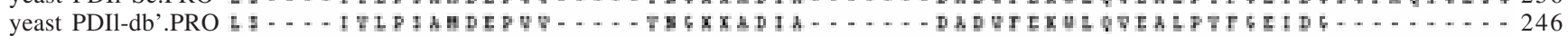

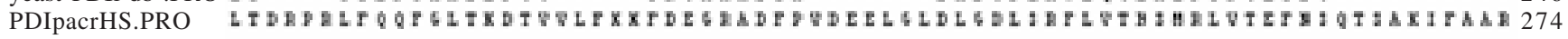

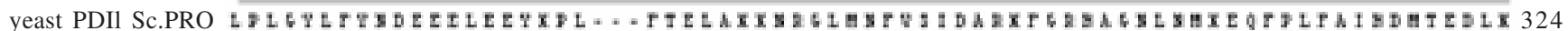

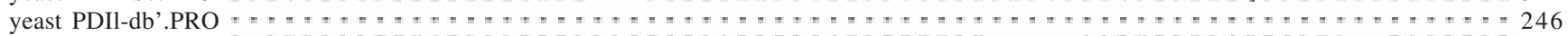

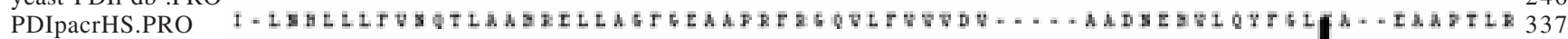

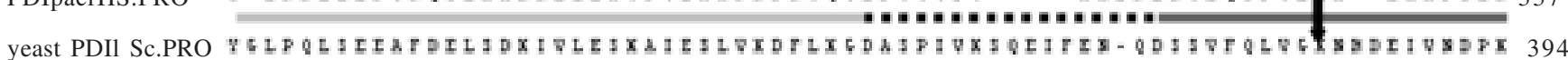

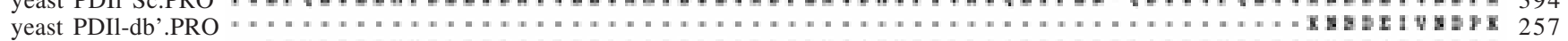

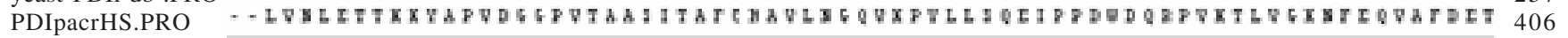

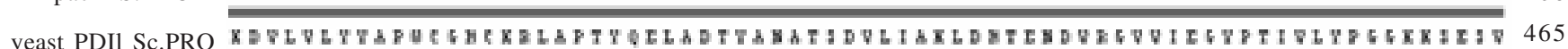

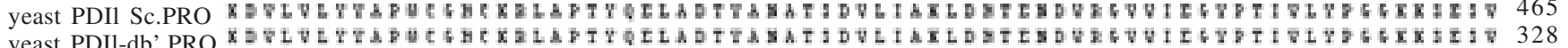

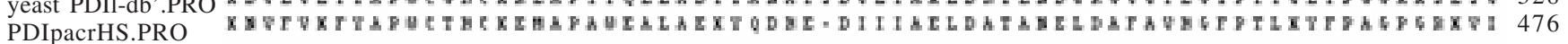
yeast PDIl Sc.PRO v

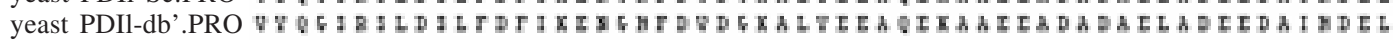

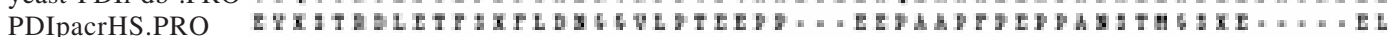

Fig 2 Primary structure of yeast PDI, pdilÄb'x and human pancreas PDI. a domain organization of PDI based on the yeast three dimensional structure (Tian et al. 2006), b multiple sequences alignment of Saccharomyces cerevisiae PDI1 (yeast PDI1Sc.PRO), pdi1 Äb'x (yeast PDI1 db'.PRO) and human pancreas PDI (PDIpancrHS.PRO). 
of IPTG induced the lacUV5 promoter to produce T7 RNA polymerase thereby allowing transcription of the PDI1 gene. Proteins were isolated from the $E$. coli cultures as described in Material and Methods. The full length PDI1 appeared as a protein with molecular weight of approximately $60 \mathrm{kDa}$ on SDS-PAGE while the molecular weight of pdi $1 \Delta b$ ' $x$ was $45 \mathrm{kDa}$ (Fig 4). These are in agreement with the predicted molecular weight from deduced amino acids in which full length PDI1 consists of 522 amino acid residues while pdi $1 \Delta$ b' $x$ contains 386 amino acid residues.

Mutant pdi1 $\Delta b$ ' $x$ has Lower Reductase Activity and is Proteinase K Sensitive. To determine whether deletion of b'x region affected PDI activity, the ability of both pdi $1 \Delta b$ ' $x$ mutant and full length PDI1 to catalize the reductive cleavage of insulin was determined. The in vitro assay for PDI activity in the crude bacterial cell extract showed that specific activity of the pdi $1 \Delta \mathrm{b}^{\text {' } x}$ was $1.4 \times 10^{3} \mathrm{U} \mathrm{mg}^{-1}$ which is approximately $50 \%$ of that of the full length PDI1 $\left(2.8 \times 10^{3} \mathrm{U} \mathrm{mg}^{-1}\right)$.

To know the stability of the yeast PDI lacking of $b^{\prime} x$ toward Proteinase K, the pdi1 $\Delta b$ ' $x$ and full length PDI were treated with Proteinase K. Proteolysis of crude bacterial cell extracts was carried out using different concentration of proteinase $\mathrm{K}$. Western blot analysis using anti yeast PDI antibody showed that a significant amount of pdi $1 \Delta b$ 'x were digested upon the increase of Proteinase $\mathrm{K}$ concentration. There is hardly pdi $1 \Delta b^{\prime} x$ left after treatment with $10 \mathrm{mg} \mathrm{mL}^{-1}$ of proteinase K (Fig 5, lane 8). The full length PDI1 remains stable upon Proteinase K treatment (Fig 5). A lower band observed in the full length PDI could be the degradation product during protein preparation. This results suggest that pdi $1 \Delta b$ ' $x$ mutant is more susceptible to Proteinase $\mathrm{K}$ degradation.

Mutant pdi1 $\Delta \mathbf{b}$ 'x can Support Yeast Viability. Since PDII is an essential gene, a plasmid-shuffle procedure to observe the function of mutant pdi $1 \Delta \mathrm{b}$ ' $x$ on supporting yeast viability was conducted. The recombinant plasmid pUKC639-GAL1pdi1 $\triangle b$ ' $x$ containing a $L E U 2$ selectable marker was introduced into a yeast strain 2736 . The strain 2736 containing pdil::HIS3 null mutation carried a plasmid-borne GAL1-PDI1 with a URA3 marker (Tachibana and Steven 1992). After transformation, the cells were grown in a medium containing 5 FOA which allow cells to lose its URA based plasmid-containing full length PDI1. Cells grown in the FOA medium indicated that the newly introduced $p d i \Delta b^{\prime} x$ mutant is able to complement the chromosomal pdil null mutation.

The Growth of $p d i 1 \Delta b$ ' $x$ Yeast is Almost the Same as the Full Length PDII Yeast. The effect of b'x deletion on the growth rate of yeast cell was investigated by growing the yeast 2736 carrying full length $P D I 1$ and $2736 \mathrm{D}$ containing pdil $\Delta b$ ' $x$ in rich media containing galactose at $30{ }^{\circ} \mathrm{C}$. The growth rate of yeast carrying full length $P D I 1$ was $0.13 \mathrm{U}$ $\mathrm{OD}_{600}$ per $\mathrm{h}$, while $2736 \mathrm{D}$ had a growth rate of $0.12 \mathrm{U} \mathrm{OD}_{600}$ per h. The results show that pdil $\Delta b^{\prime} x$ and full length PDII can support the yeast growth at nearly the same growth rate $30^{\circ} \mathrm{C}$.

The pdi1 $\Delta b$ 'x Yeast Impaired Severely at High Temperature. Protein disulphide isomerase is one of the main cellular chaperones in the ER. Under temperature stress, the amount of unfolded proteins accumulated in the ER will increase. We further investigated the effect of b'x deletion on the yeast growth at temperature stress $\left(37^{\circ} \mathrm{C}\right)$. As shown in Fig 6 both 2736 and 2736D grew well at $30^{\circ} \mathrm{C}$. However, reduced growth were observed for both yeast strains at $37^{\circ} \mathrm{C}$ in which 2736D growth impaired severely.

The pdi1 $\Delta b$ ' $x$ Yeast Shows No Cell Wall Defect. To study whether the b'x region is responsible in the folding of cell wall forming protein, the pdil $\Delta b^{\prime} x$ mutant was grown in a medium containing calcofluor white. Defect on the cell wall forming protein leads to calcofluor sensitive phenotype. The pdi $1 \Delta b$ 'x mutant seems to grow in a similar manner as the full length PDI1 (Fig 7) which indicates that there is no defect on the synthesis of cell wall in pdi $1 \Delta b$ ' $x$.

\section{DISCUSSION}

Protein disulphide isomerase as a key player in the formation of correct disulphide bond in protein was discovered 40 years ago by Anfinsen and co workers (Goldbeger et al. 1964). It is a member of thioredoxin superfamily which consists of five consecutive domains $a, b$, b' a' and c (Fig 2A). There have been many studies reported on the contribution of each domain or domain combinations in PDI activities both as an enzyme or as a chaperone. We have constructed a yeast PDI without b' domain and x-linker in which the $\mathrm{N}$ - terminals of 19 amino acid residues of the b' domain and 7 amino acid residues of the a' domain were still included (Fig 2B).

The pdi $1 \Delta$ b' $x$ was expressed as a soluble protein in E. coli and retained only $50 \%$ of its activity in the reductive cleavage of insulin B chain. This represented that b' domain is required to PDI activity. However, other domains is also capable of interacting with insulin. Other study has shown that deletion of a,b and b'a'c domains of bovine PDI resulted in a decrease of insulin reductase activity of $94 \%$ and $78 \%$, respectively (Sun et al. 2000). Since pdi1 $\Delta$ b'x still has two a and a' active site domains which are responsible in the reduction of disulphide bond of insulin, hence it possesess higher activity compared to the other two bovine PDI variants. Several researchs have shown that multi domain fragments had enhanced catalytic activities compared with individual a or a' domains, that the b' domain had a particularly important role in this enhancement (Darby et al. 1998; Klappa et al. 1998; Tian et al. 2006).

To analyze whether there is a correlation between stability as defined by protease-resistance, crude bacterial cell extract containing pdi $1 \Delta b$ 'x mutants was treated with Proteinase K. It appeared that pdi $1 \Delta \mathrm{b}^{\prime} \mathrm{x}$ is protease sensitive while the full length PDI1 was only slightly affected at high Proteinase K concentration (Fig 4). The stability of full length human PDI toward Proteinase $\mathrm{K}$ had also been reported (Klappa et al. 2000). From the crystal structure of PDI1, it was found that the two flexible catalytic a and a' domains are attached to more rigid b' and b domains (Tian et al. 2006), hence deletion of b'x region will decrease conformational stability.

Furthermore, we had investigated how the function of mutant yeast PDI lacking of b'x to support yeast viability. Plasmid shuffling experiment showed that pdil $\Delta b$ 'x can rescue the pdil::HIS3 null mutation in 2736 yeast strain. LaMantia and Lennarz (1993) have demonstrated that pdi1 mutant containing a, b and b' domains can support yeast 


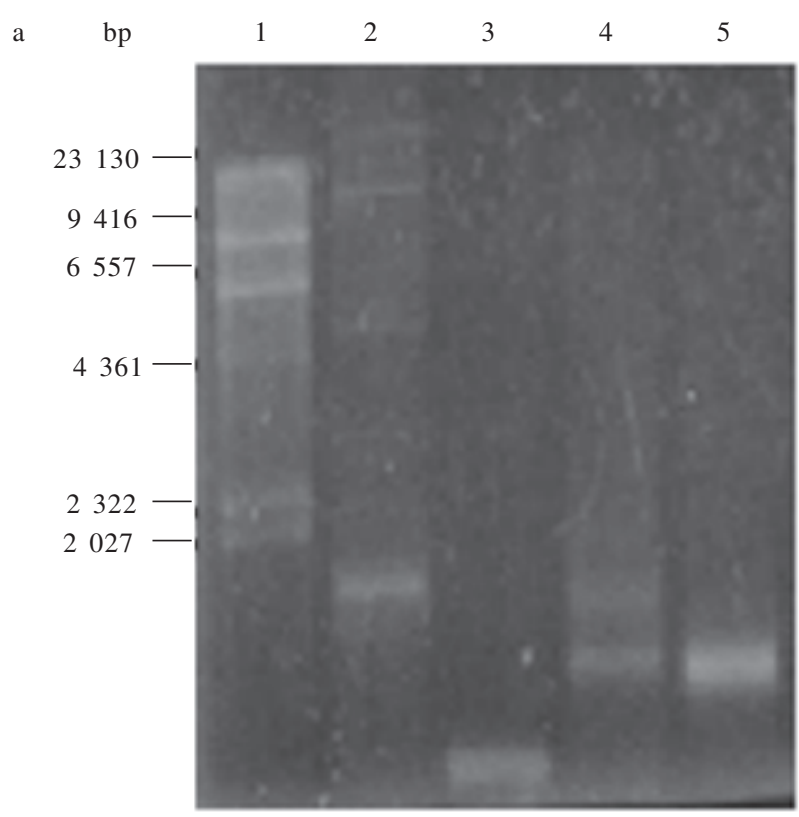

Fig 3 PCR product: Lane 1, DNA $\lambda$ /Hind III; lane 2, full length PDI1 (1569 bp); lane 3, $c^{\prime}-a$ fragment (447 bp); lane 4 and 5, pdiläb’x (1190 bp).

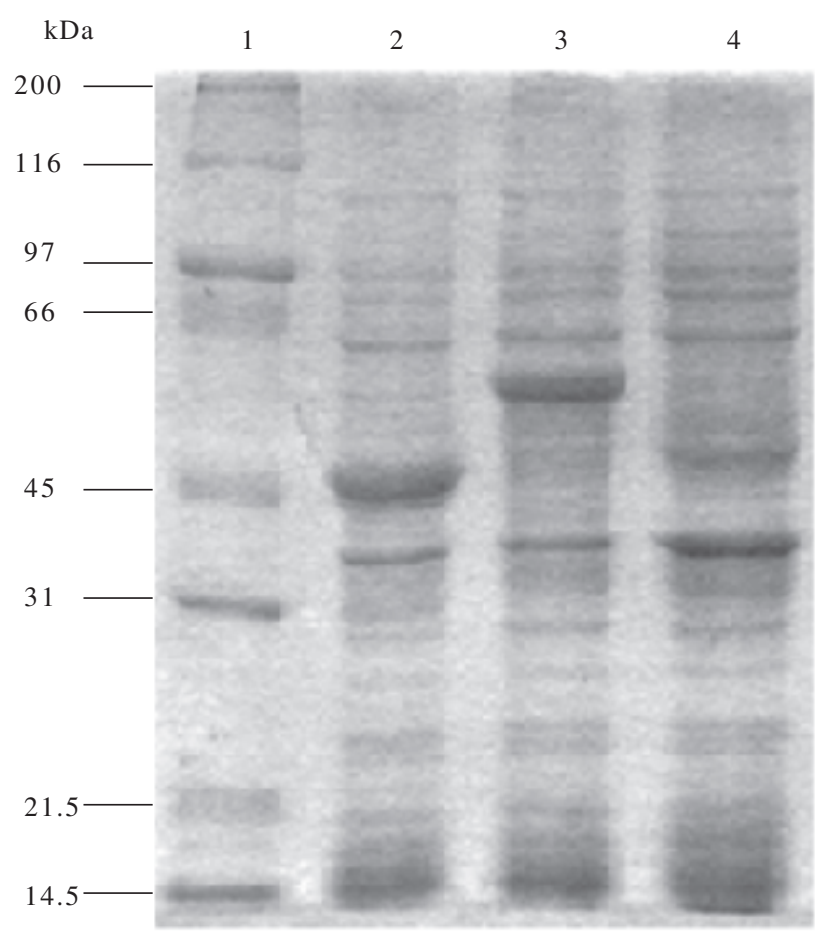

Fig 4 SDS-PAGE analysis of pdi1 Äb'x and full length PDI1. Lane 1, protein marker; lane 2, pdi1Äb'x; lane 3, full length PDI1.

growth, while the ab domain has lost its essential function in yeast viability. We speculate that in the pdi $1 \Delta b^{\prime} x$, the abac domains might adopt the modular U shape structure which presumably able to interact with polypeptide substrate to carry out its activity in vivo. Crystal structure of pdi1 $\Delta \mathrm{b}^{\prime} \mathrm{x}$ would be able to reveal the three dimensional structure of the mutant.

Protein disulfide isomerase can act both as a catalyst and also as a chaperone. Deletion of the b' domain significantly slows down the refolding rate of misfolded RNase (Darby et

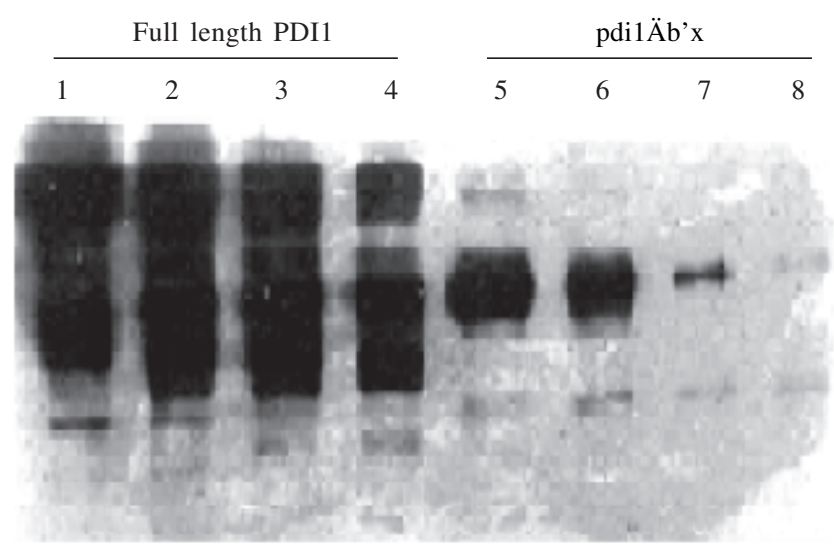

Fig 5 Western blot analysis of full length PDI1 and pdi1 Äb' after treatment with Proteinase $\mathrm{K}$. Lane 1 and $5,0 \mu \mathrm{g} \mathrm{mL}^{-1}$; lane 2 and 6 , $1 \mu \mathrm{g} \mathrm{mL} \mathrm{m}^{-1}$; lane 3 and $7,3 \mu \mathrm{g} \mathrm{mL}^{-1}$; lane 4 and $8,10 \mu \mathrm{g} \mathrm{mL}^{-1}$.

\begin{tabular}{|c|c|c|c|c|c|}
\hline \multirow{2}{*}{ Temperature } & \multirow{2}{*}{$\begin{array}{c}\text { Saccharomyces } \\
\text { cerevisiae }\end{array}$} & \multicolumn{4}{|c|}{ Dilution } \\
\hline & & $10^{-1}$ & $10^{-2}$ & $10^{-3}$ & $10^{-4}$ \\
\hline $30^{\circ} \mathrm{C}$ & $\begin{array}{c}2736 \\
2736 \mathrm{D}\left(p d i 1 \ddot{A} b^{\prime} x\right)\end{array}$ & & 6 & & \\
\hline $37{ }^{\circ} \mathrm{C}$ & $\begin{array}{c}2736 \\
2736 \mathrm{D}\left(p d i 1 \ddot{A} b^{\prime} x\right)\end{array}$ & & & 8 & \\
\hline & & - & 8 & & * \\
\hline
\end{tabular}

Fig 6 The effect of temperature stress on yeast growth. The parent 2736 and mutant pdil $\ddot{A} b^{\prime} x$ 2736D yeasts were first grown in minimal media at $30{ }^{\circ} \mathrm{C}$ for $2 \mathrm{~d}$. The cultures were then diluted to obtain $\mathrm{OD}_{600}$ of 1.5 . The yeasts were spotted in serial dilutions from $10^{-1}$ to $10^{-4}$ on YEPGal at 30 and $37^{\circ} \mathrm{C}$. Growth was scored after $4 \mathrm{~d}$ incubation.

\begin{tabular}{|c|c|c|c|c|}
\hline Saccharomyces & & Dil & ion & \\
\hline cerevisiae & $10^{-1}$ & $10^{-2}$ & $10^{-3}$ & $10^{-4}$ \\
\hline 2736 & & & & 30 \\
\hline 2736D ( $\left.p d i-1 \ddot{A} b^{\prime} x\right)$ & & & & $\boldsymbol{H}$ \\
\hline
\end{tabular}

Fig 7 The effect of calcofluor on yeast growth. The parent 2736 and mutant $p d i \ddot{A} b^{\prime} \times 2736 \mathrm{D}$ yeasts were first grown in minimal media at $30{ }^{\circ} \mathrm{C}$ for $2 \mathrm{~d}$. The cultures were then diluted to obtain $\mathrm{OD}_{600}$ of 1.5 . The growth rates of yeasts strains were evaluated by spotting 5 ì of serial dilutions of yeast cells on YEPGal containing calcofluor $(50 \mathrm{ig} \mathrm{mL}-1)$. The cells were incubated at $30{ }^{\circ} \mathrm{C}$ for $4 \mathrm{~d}$.

al.1998; Tian et al. 2006 ). Furthermore, it has also been demonstrated that the b' domain is generally important for refolding of proteins, whereas the b domain might contribute to the refolding rate in selected cases (Tian et al. 2006). Our data showed that the growth of pdil $\Delta b^{\prime} x$ yeast strain producing the a,b,a',c protein was reduced dramatically at non permissive temperature. At high temperature the rate of protein unfolding increseases, hence the chaperone role of PDI becomes predominant. Taken together, we propose that the presence of b' $x$ region together with $b$ domain is required in assisting refolding of misfolded protein at non-permisive temperature. 


\section{ACKNOWLEDGEMENTS}

This research was funded partially by University Research for Graduate Education from Ministry of National Education. We gratefully acknowledge P. Klappa for his assistance in Proteinase K sensitive experiment,

\section{REFERENCES}

Darby NJ, Penka E, Vincentelli R. 1998. The multi-domain structure of protein disulfide isomerase is essential for high catalytic efficiency. J Mol Biol 276:239-47.

Denisov AY, Maattanen P, Dabrowski C, Kozlov G, Thomas DY, Gehring K. 2009. Solution structure of the bb' domains of human protein disulfide isomerase. FEBS J 276:1440-9.

Farquhar R, Honey N, Murant SJ, Bosier P, Schultz L, Montgomery D, Ellis RW, Freedman RB, Tuite MF. 1991. Protein disulfide isomerase is essential for viability in S. cerevisiae. Gene 108:81-9.

Freedman RB, Hirst R, Tuite MF. 1994. Protein disulfide isomerase building bridges in protein folding. Trends Bioch Sci 19:331-5.

Goldbeger RF, Epstein CJ, Anfinsen CB. 1964. Purification and properties of microsomal enzyme system catalyzing the reactivation of reduced ribonuclease and lysozyme. J Biol Chem 239:1406-10.

Ito H, Fukuda Y, Murata K, Kimura A. 1983. Transformation of intact yeast cells treated with alkali cations. J Bacteriol 153:163-8.

Klappa P, Koivunen P, Pirneskoski A, Karvonen P, Ruddock LW, Kivirikko KI, Freedman RB. 2000. Mutations that destabilize the a' domain of human protein disulfide isomerase indirectly affect peptide binding. J Biol Chem 18:13213-8.

Klappa P, Ruddock LW, Darby NJ, Freedman RB. 1998. The b' domain provides the principles peptides-binding sites of protein disulfide isomerase but all domains contribute to binding of misfolding protein. EMBO J 17:927-35.

Laemli UK. 1970. Cleavage of structural proteins during the assembly of the head of bacteriophage T4. Nature 227:680-5.

LaMantia M, Lennarz WJ. 1993. The essential function of yeast protein disulfide isomerase does not reside in its isomerase activity. Cell 74:899-908.

Pihlajaniemi T, Helakoski T, Tasanen K, Myllyla R, Hntala ML, Koivu J, Kivirikko KI. 1987. Molecular cloning of the subunit of human prolyl 4-hydroxylase. This subunit and protein disulfide isomerase are products of the same gene. EMBO J 6:643-9.

Powers SL, Robinson AS. 2007. PDI improves secretion of redoxinactive b-glucosidase. Biotechnol Prog 23:364-9.

Sambrook J, Fritsch EF, Maniatish Y. 1989. Molecular cloning: a laboratory manual. $2^{\text {nd }}$ ed. New York: Cold Spring Harbor Pr.

Sun XX, Yong Y, Liu HP, Chen SM, Wang CC. 2000. Contributions of protein disulfide isomerase domains to its chaperone activity. Biochim Biophys Acta 1481:45-54.

Sutter DK, Hostens K, Vandekerckhove Y, Fier W. 1994. Production of enzymatically active rat protein disulfide isomerase in Escherichia coli. Gene 141:163-70.

Tachibana C, Steven TH. 1992. The yeast EUG1 gene encodes an endoplasmic reticulum protein that is functionally related to protein disulfide isomerase. Mol Cel Biol 12:4601-11.

Tian G, Xiang S, Noiva R, Lennarz WJ, Schindelin H. 2006. The crystal structure of yeast protein disulfide isomerase suggests cooperativity between its active sites. Cell 124:61-73.

Wang CC, Tsou CL. 2003. Protein disulfide isomerase is both an enzyme and a chaperone. FASEB J 7:1515-7.

Wetterau JR, Combs KA, McLean LR, Spinner SN, Aggerbeck LP. 1991. Protein disulfide isomerase appears necessary to maintain the catalytically active structure of the microsomal triglyceride transfer protein. Biochemistry 30:9728-35. 